\title{
The Effect of Micro-teaching Practices on the Professional Self-determination Beliefs of Teacher Candidates in University Education in Turkey
}

\author{
Feti Celik (Corresponding author) \\ Education Facülty, Mehmet Akif Ersoy University, Burdur, Turkey \\ E-mail: fetifeti135@gmail.com
}

Received: June 2, 2019 Accepted: July 21, 2019 Published: August 7, 2019

doi:10.5296/jei.v5i2.14877ＵRL: https://doi.org/10.5296/jei.v5i2.14877

\begin{abstract}
The aim of this study is to show the effect of micro-teaching technique applied to teacher candidates in pedagogical formation program in Turkish universities on the perception of professional self-efficacy. Unequalized experiment and quasi-experimental method with control group were used in the study. The study group of the study consisted of 55 prospective teachers studying in the 2018-2019 fall semester pedagogical formation program of the Faculty of Education of Mehmet Akif Ersoy University. The research data were collected through the Teacher Self-Efficacy Scale according to the pre-test post-test application model. In the research, presentations were video-taped. The video footage was watched in the classroom and criticisms and discussions were made about how a better presentation could be. The course activities, in which each participant prospective teacher made three presentations during the activity period, were carried out for 12 weeks. According to the findings, the experimental group of teachers in terms of self-sufficiency beliefs see themselves more adequate than the control group. However, there was no differentiation between groups in the subdimension of self-efficacy.
\end{abstract}

Keywords: Pedagogical formation, Micro teaching, Teacher training, Experimental research

\section{Introduction}

Initial teaching efforts date back to the beginning of human history. Previously, these efforts were seen as an occupation. Afterwards, they underwent significant changes towards becoming a profession with the division of labor required by scientific developments and technological innovations. It had been discussed for a long time whether teaching is a profession or not. At some point in time, it was even deemed as a semi-profession (Bourdoncle, 1989). In today's world, it is pointed out that teaching is a unique profession 
and that more qualified personnel should be trained in line with the requirements of the era in this field (Bilen, 1996; Duran, 2001; Gündüz, 1997; Kepçeoğlu, 1988; Şişman, 2000; Tezcan, 1988). The importance of this issue lies in developing effective training programs (Cotrell \& Doty, 1971). In the education program, which is integrated with today's realities, the selection of prospective teachers, pre-service and post-service training, the period of internship and the monitoring and evaluation practices in this period can be considered in the concept of teacher training.

\subsection{Teacher Self-efficacy}

In the teacher training process, a professional need to carry some qualifications. At the beginning of these qualities the belief that teaching skills and proficiency can achieve success even in children who have difficulty learning comes. Teaching proficiency arises from several personal characteristics of the teacher that are associated with student achievement (Woolfolk, 1998). This personal feature, which varies in different fields, such as mathematics, foreign language and fine arts, can be seen as the limits of the field teacher's self-sufficiency. Self-efficacy is one of the important concepts first emphasized in Bandura's Social Cognitive Theory (Aşkar \& Umay, 2001; Bıkmaz, 2004; Ekici, 2009; Morgil, Seçken, \& Yücel, 2004; Senemoğlu, 2009). Bandura (1977) refers to self-efficacy as "one's belief in their own ability to plan and perform the forms of behaviors they need to manage in forward-looking situations." According to Lunenburg (2011) self-efficacy was considered an action-specific version of self-esteem (Redmond, 2015). In this context self-efficacy refers to the personal judgment of the individual about his ability to perform in any field (Bandura, 1997). It can be thought that the self-efficacy perception of the teachers in the teaching process will reflect on the success of the students in the classroom activities and the quality of the educational activities in the school will be more successful in the profession of a teacher with high self-efficacy perception. In this context, one of the important points to be emphasized is to increase the prospective teachers' self-efficacy beliefs about the teaching profession. The concept of self-efficacy is related to each individual's belief in these abilities rather than their subjective perception abilities (Akkoyunlu, Orhan, \& Umay, 2005). It is possible to say that this belief is fed by previous experiences, indirect experiences, positive feedback (Yıldırım \& Illhan, 2010). In addition, it is seen that self-efficacy focuses on the selection of activities, combating difficulties, demonstrating effort and performance (Aşkar \& Umay, 2001).

Self-efficacy beliefs have a significant impact on the way individuals determine goals, identify strategies to achieve these goals, their work motivation, the feelings they have towards other people, and their choices in life (Bandura, 1977). Bandura (1986) defines the self-efficacy belief as the individual's judgment on the capacity to organize and successfully conduct the activities necessary to demonstrate a certain performance. According to Bandura (1995), human behavior is based on two sources: self-efficacy and expectation of outcome. The self-efficacy belief includes beliefs about the individual's beliefs about individual competencies that affect a given task, and the expectation of an outcome is certain actions to have certain consequences. A person with a high self-efficacy belief in any subjects has confidence in the subject and this confidence is reflected positively in the behavior of the person (Bandura, 1977). In order to improve the confidence level of the trainees, they should 
be able to see their professional knowledge adequate and to solve the problems they face successfully. In order to do this, it is necessary to teach both knowledge of field knowledge and field education, especially in teacher education (Altunçekiç, Yaman, \& Koray, 2005). According to Bandura, teacher self-efficacy belief is defined as the belief that a teacher can achieve the desired results in their learning even when the students are not motivated enough (Tschannen-Moran \& Hoy, 2001). According to Özdemir (2008), the self-efficacy beliefs and perceptions of teachers about their abilities and skills play an important role in the quality of prospective teachers' teaching and to overcome the problems they face in the teaching process. The adoption of all these values necessitates the raising of self-efficacy beliefs of the prospective teachers towards the teaching profession in order to solve the problems encountered in the profession through the acquisition of competencies. In order to clarify the knowledge, skills and attitudes that teachers should possess, teachers' general field competencies in teacher competence framework program prepared by MEB (2008) are mentioned in detail. Field competencies require prospective teachers to be in appropriate learning-teaching environments during their university education and to have appropriate education in their professional fields.

The research (Akbulut, 2006; Bümen \& Özaydın, 2013; Kahyaoğlu \& Yangın, 2007; Üstün \& Tekin, 2009) about prospective teachers' self-efficacy beliefs related to the teaching profession revealed that prospective teachers' self-efficacy beliefs increased significantly. The fact that prospective teachers have high self-efficacy beliefs towards teaching will also have a positive effect on the teacher's occupational behavior patterns. According to this understanding, internal factors such as love of profession, sense of service, professional spirit and motivation have a special importance in teaching (Kavcar, 2002). In other words, in the literature, there are studies about the motivations and attitudes of teachers related to the teaching profession and their self-efficacy beliefs about the teaching profession (Arastaman, 2013; Oğuz \& Topkaya, 2008). However, it was found that the number of studies investigating pedagogical formation students' self-efficacy belief levels about teaching profession was very limited.

\subsection{Micro-teaching Applications in Teacher Training}

In today's teacher education programs, a number of methods and strategies are used to increase the effectiveness of these programs, based on the acquisition of professional competences and skills. According to Benton-Kupper (2001), teacher education programs, which are combined with micro-teaching in the 21 st century, are still active and powerful and are very useful when viewed from a student perspective (Tok, 2016). Micro-teaching can also be defined as a teaching technique which is used especially for teachers' pre-service training and aims to train them systematically in terms of their primary teaching behavior. In this technique, it is essential to develop teaching skills by identifying the points that are strong and weak. With such practices, prospective teachers can learn the teaching skills that must be exhibited in a classroom by analyzing, without encountering the actual teaching environment. In addition, thanks to the video recordings used in the micro-teaching technique, the teacher can observe the interactions of students, both with him and each other (Berg \& Smith, 1996). Micro teaching is mainly based on the social learning theory of Bandura (1982). 
Micro-teaching was first developed at Stanford University in 1960 as part of an experimental program to improve the quality of teacher education (Demirel, 2000). It is widely used in the teaching of micro-teaching in teacher education and in the analysis of skills in this application process in England (Bisset, 1999). Micro-teaching practices were included in the education faculties programs for the first time in 1990-1991 in teacher training in Turkey (Uşun \& Zorlubaş, 2007).

Micro-teaching technique is very important in the demonstration of skills and knowledge in teacher behavior. There is very little risk of failure in gaining experience with micro-teaching practices. Research showed that micro-teaching practices really provide the prospective teacher with a mastery of making connections between theory and practice (Bayraktar, 1982; Benton-Kupper, 2001; Blankenburg \& Thompson, 1971; Çakir \& Aksan, 1992; Fernández \& Robinson, 2006; Higgins \& Nicholl, 2003; Kazu, 1997; Nortman, 1989). In other words, in order to establish the link between theory and practice in the success of the teaching profession, the prospective teacher, with this technique, reinforces his cognitive competence with his professional skills. In this context, according to Kazu (1997), the aim for prospective teachers is to apply a technique rather than to teach a subject.

The importance of Special Teaching Methods in teacher education programs cannot be denied. During the course on Special Teaching Methods, the prospective teacher tries to prepare for the future teaching role. For this reason, special teaching methods are important for the prospective teachers to gain their first experiences during their professional life. In this way, it is thought that it will make a significant contribution to the acquisition of teaching profession skills by including micro-teaching applications in the teaching of Special Teaching Methods course.

\subsection{Purpose of the Study}

The aim of this study is to determine the effect of micro-teaching technique learning outcomes on teacher self-efficacy beliefs of prospective teachers. For the sake of this purpose, the hypothesis of the research was formed as follows:

"The change in the self-belief scores of teacher candidates who study with micro-teaching technique differs significantly fron traditional teaching methods and techniques".

In line with the hypothesis of the research, the following questions (sub-objectives) were sought:

(1) Is there a significant difference between the experimental and control groups self-efficacy sub-dimensions (academic, occupational, social, intellectual) and overall scale pre-test scores?

(2) Is there a significant difference between the experimental and control groups self-efficacy sub-dimensions (academic, professional, social, intellectual) and overall scale post-test scores?

(3) Does the change between the change in the pre-test and post-test self-efficacy total scores 


\section{Macrothink Alnstitute"}

of the experimental group and the pre-test and post-test self-efficacy total scores of the control group significantly differentiate from each other?

\section{Method}

In order to determine the difference between the teachers' self-efficacy beliefs of the prospective teachers with micro-teaching techniques in the research (experimental group) and prospective teachers who teach using traditional teaching methods and techniques (control group), a quasi-experimental method with unequalized control group was used. The unequalized control group model is very similar to the pretest-posttest control group model. The most important difference between the two models is the random creation of groups rather than equalization of them (Karasar, 2011). Table 1 shows the arrangement of Büyüköztürk's (2002) method for experimental design with experimental and control groups according to this study.

Table 1. Research design

\begin{tabular}{|l|l|l|l|l|l|}
\hline & & Group & Pre test & Operation & Last test \\
\hline Pedagogical formation \\
$\begin{array}{l}\text { area randomly selected } \\
55 \text { teachers nominated }\end{array}$ & $\mathrm{R}$ & $\begin{array}{l}\text { Experiment } \\
\text { (The 29 randomly selected } \\
\text { teacher candidate })\end{array}$ & O1 & $\begin{array}{l}\text { Micro-teaching } \\
\text { technique }\end{array}$ & O3 \\
\cline { 2 - 6 } & $\mathrm{R}$ & $\begin{array}{l}\text { Control } \\
\text { (The 26 randomly selected } \\
\text { teacher candidate })\end{array}$ & O2 & $\begin{array}{l}\text { Current teaching } \\
\text { methods and } \\
\text { techniques }\end{array}$ & O4 \\
\hline
\end{tabular}

In the above table, $\mathrm{R}$ shows the subjects that are assigned to groups in a neutral manner; $\mathrm{O} 1$ and $\mathrm{O} 3$ show the pre-test and last test measurements of experimental group; $\mathrm{O} 2$ and $\mathrm{O} 4$ show the pre-test and post-test measurements of the control group.

\subsection{Study Group}

The study group consisted of 55 prospective teachers participating in the pedagogical formation certificate program at Mehmet Akif Ersoy University Faculty of Education during the 2018-2019 academic fall semester. Demographic data of the study group are given in Table 2. 
Table 2. Demographic information of the working group

\begin{tabular}{|l|l|l|l|}
\hline Variable & Category & Frekans (f) & Percentages (\%) \\
\hline \multirow{5}{*}{ Chapter } & Justice & 5 & 9.1 \\
\cline { 2 - 4 } & Theology & 5 & 9.1 \\
\cline { 2 - 4 } & Music & 3 & 5.5 \\
\cline { 2 - 4 } & Fine Arts & 12 & 21.8 \\
\cline { 2 - 4 } Gender & Sociology & 15 & 27.3 \\
\cline { 2 - 4 } & Philosophy & 15 & 27.3 \\
\hline & Woman & 45 & 81.8 \\
\cline { 2 - 4 } & Male & 10 & 18.2 \\
\hline
\end{tabular}

When Table 2 is examined, it is seen that most of the prospective teachers in the study group graduated from the department of philosophy and sociology. Although the number of prospective teachers is equal in the department of justice and theology, it is low in total. There are only three prospective teachers in the music department. In addition, the large majority in the favor of women in terms of gender of prospective teachers is prominent.

\subsection{Data Collection}

In the development stage of the Teacher Self-Efficacy Belief Scale, the studies (Bandura, 2006; Cerit, 2010; Capa et al., 2005; Diken, 2004; Emmer \& Hickman, 1991; Palanc1, 2004; Tschannen-Moran \& Hoy, 2001) of the literature were scanned in detail by Çolak, Yorulmaz, and Altınkurt (2017) and developed scales were used in this field. Exploratory and confirmatory factor analysis was performed for the construct validity of the scale, respectively. As a result of validity studies, a 27-item and four-factor structures including academic self-efficacy ( 5 items), professional self-efficacy ( 7 items), social self-efficacy ( 8 items) and intellectual self-efficacy (7 items) was emerged (Çolak et al., 2017). The scale is in five likert type: it is scored between (1) Agree, (5) Do not agree (Çolak et al., 2017). In the reliability analyzes conducted by Çolak et al. (2017), the alpha coefficient was calculated as .75 for the academic self-efficacy factor; .86 for the professional self-efficacy factor, .88 for the social self-efficacy factor, .87 for the intellectual self-efficacy factor, and .93 for the whole scale.

In our study, it was calculated as .84 for the academic self-efficacy factor for pre-test, .87 for the professional self-efficacy factor, .89 for the social self-efficacy factor, .88 for the intellectual self-efficacy factor, and .94 for the whole scale. It was calculated as 78 . for the academic self-efficacy factor, .86 for the professional self-efficacy factor, .90 for the social self-efficacy factor, .89 for the intellectual self-efficacy factor, and .94 for the whole scale for the post test. According to these results, it can be said that the scale is highly reliable (Kalayc1, 2006; Yildırım \& İlhan, 2010). 


\subsection{Data Analysis}

In the analysis of the data, descriptive statistics such as frequency (f), arithmetic mean $(\bar{X})$, percentage (\%) and standard deviation (S) were used. Skewness and kurtosis values were examined in order to determine whether the data were distributed normally. Shapiro-Wilk-W test was also performed. Shapiro-Wilk-W test is recommended when the number of data is below 30 (Can, 2014). The findings for normality tests are given in Table 3.

Table 3. The assumption of normality tests

\begin{tabular}{|l|l|l|}
\hline & Pre-test total points & Post-test total points \\
\hline Arithmetic average & 3.80 & 4.17 \\
\hline Median & 3.80 & 4.19 \\
\hline Standard deviation & .63 & .46 \\
\hline Minimum & 2.01 & 2.82 \\
\hline Maximum & 4.69 & 4.96 \\
\hline Range & 2.68 & 2.14 \\
\hline Skewness & -.400 & -.509 \\
\hline Kurtosis & -.336 & -.163 \\
\hline
\end{tabular}

Table 3 revealed that the skewness and kurtosis values did not exceed \pm 1 and the Shapiro-Wilk-W test did not show any significant difference except for the pretest scores $(\mathrm{p}>$ $05)$. It was observed that the skewness and kurtosis coefficients obtained from the pre-test scores did not exceed the limit of \pm 1.96 by dividing the standard error. If the value obtained from the standard error section of the skewness or kurtosis coefficients remains at the limit of \pm 1.96 , it can be interpreted that the data are normally distributed (Can, 2014). In addition, for both the pre-test and the post test, the sub-dimensions of the scale were also tested for normality. It was seen that the sub-dimensions of the scale did not exceed the \pm 1 value of the skewness and kurtosis values in both the pre-test and post-test and that the value obtained from the standard error section of the skewness and kurtosis values did not exceed \pm 1.96 value.

According to these findings, the data are normally distributed. In the experimental and control groups, t-test was used for unrelated samples in order to determine whether there was a significant difference between the pre-test scores of the sub-dimensions of the scale. In addition, Repeated Measures Anova was performed for repeated measurements to determine whether the changes in the scores of teaching self-efficacy before and after the experiment showed significant differences. 


\subsection{Experimental Operations}

In the study, micro-teaching technique was used for the experimental group; and cooperative learning, presentation, discussion, case study, demonstration, brainstorming, question-answer, drama, simulation, programmed instruction, brain-based learning, etc. teaching methods and techniques were applied for the control group.

It is useful to include video in micro-teaching which is an important technique in teacher education. This is considered to be a good technique (Jacques, 2000; Kpanja, 2001). Usually, for carrying out micro-teaching sessions, a portable video recorder, a TV camera, as well as a microphone for the video recorder are used (Orlich et al., 1990). Thus, the study group was given a 3-week training by the researcher. The main implementation practices carried out during this training process were as follows (Allen, 1967; Cooper \& Allen, 1970; Mohan, 2011):

(1) Planning a course, introduction (drawing attention, motivation, explaining the teaching objectives, learning about the students' prior knowledge, linking between old and new information).

(2) Reinforcing, giving clues, observing student behavior in the classroom, communicating effectively with students (voice tone, using gestures and facial expressions, being mobile, eye contact, teacher-student relationship, etc.).

(3) Using student-centered teaching methods and techniques and supporting the audiovisual materials to process the course, using the effective method to ensure motivation and participation in the course, effective communication, effective use of teaching materials to provide classroom management and finishing the course. The implementation of micro-teaching continued for a total of 36 hours for 9 weeks. Each student was planned to participate in micro teaching 3 times. Micro-teaching was carried out every three weeks for 15 minutes. Different classroom settings were provided for prospective teachers, and it was ensured that the other students had a comfortable, flexible and impartial cooperation with the candidate. The micro-teaching cycle developed by Allen (1967) and Mangal \& Mangal (2008) was used while applying the stages of micro-teaching. The stages applied during the micro-teaching lessons are as follows:

$\checkmark \quad$ Preparing a micro-lesson plan based on the prospective teaching skills.

$\checkmark$ Prospective teachers applying their teaching skills (teaching status)

$\checkmark$ Other candidates who watch the video recording after the application give feedback and make suggestions. The prospective teacher then watches himself on video and prepares a self-evaluation report.

Replanning: The prospective teacher prepares a new lesson plan to re-teach the same lesson, taking into account the oral and written feedback and suggestions, self-evaluation report.

To re-apply the teaching plan prepared in line with the suggestions. 
$\checkmark$ After the prospective teachers teach the course, the other candidates give feedback and make suggestions. Then, the prospective teacher watches himself in the video and prepares a self-evaluation report for a second time.

\section{Findings and Comments}

In order to find the answer to the sub-objectives of the study, the t-test was conducted for independent groups to determine whether the pre-test scores obtained from the sub-dimensions of the teacher self-efficacy scale of the experimental and control groups showed a significant difference. T-test results are given in Table 4.

According to the t-test results in Table 4, there was no significant difference between the academic self-efficacy pre-test scores of the experimental and control groups. [ $[(53)=-1.534$, $\mathrm{p}>$.05]. The academic self-efficacy mean scores of the prospective teacher in the experimental group $(\bar{X}=3.61)$ and the academic self-efficacy score of the prospective teachers in the control group $(\bar{X}=3.91)$ were found to be similar. Accordingly, there is no obvious difference between the experimental and control groups' pre-process academic self-efficacy beliefs. However, a significant difference is observed between the posttest scores of the experimental and control groups $[\mathrm{t}(45.75)=2.416, \mathrm{p}<.05]$. These results show that after the micro-teaching practices, the experimental group considered themselves more adequate in terms of academic self-efficacy belief than the control group.

Table 4. According to the sub-dimensions of the scale pre-test/final test scores t-test results

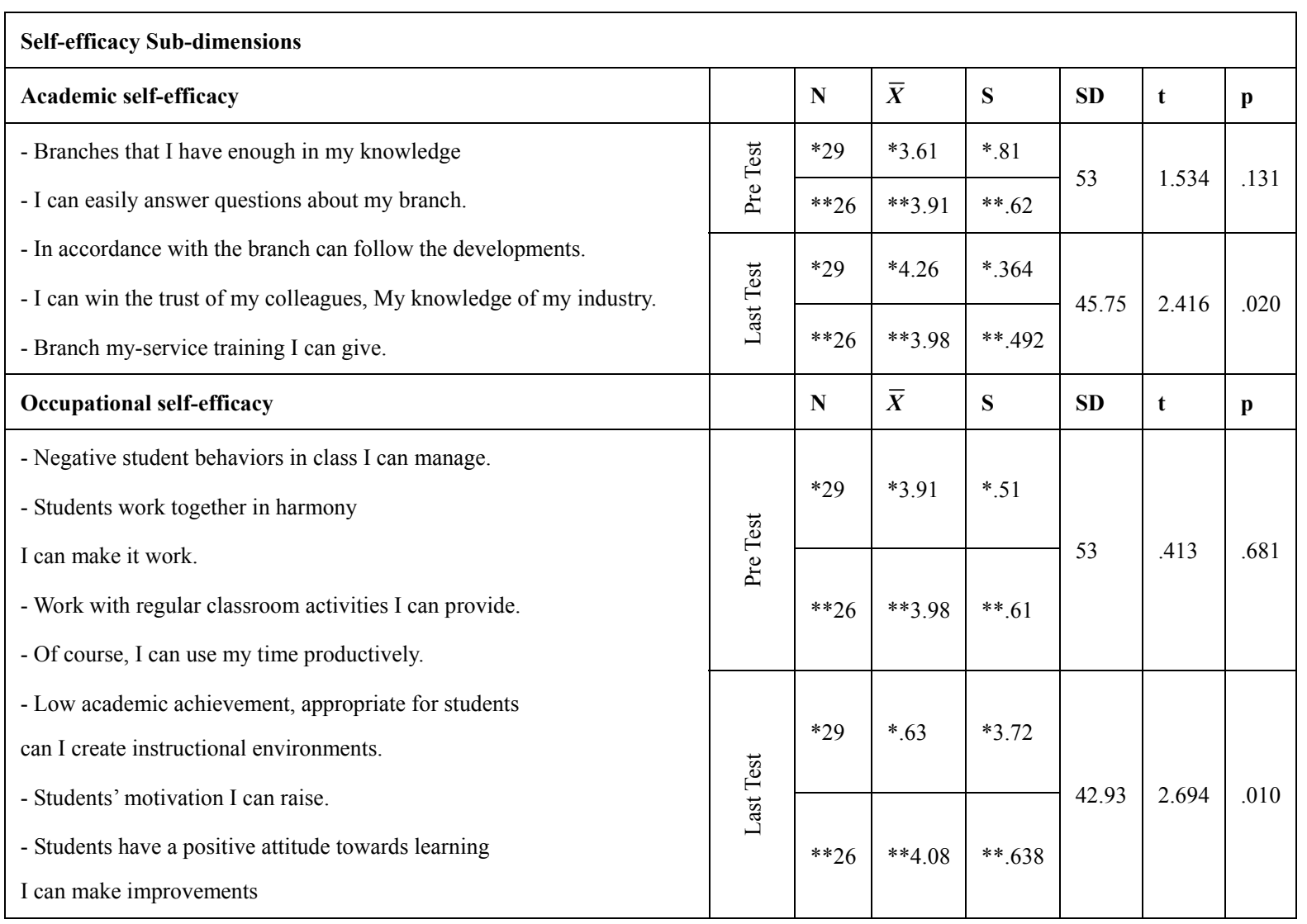




\begin{tabular}{|c|c|c|c|c|c|c|c|}
\hline Social self-sufficiency & & $\mathbf{N}$ & $\bar{X}$ & $\mathbf{S}$ & SD & $\mathbf{t}$ & $\mathbf{p}$ \\
\hline $\begin{array}{l}\text { - I can communicate better with parents. } \\
\text { - Communicate easily with someone I don't know I am able to. } \\
\text { - I can explain my thoughts in the group. } \\
\text { - I can communicate with my colleagues. }\end{array}$ & $\begin{array}{l}\overrightarrow{0} \\
\stackrel{e}{0} \\
0 \\
0\end{array}$ & $* * 26$ & $* * 3.78$ & $* * .77$ & 53 & .247 & .806 \\
\hline $\begin{array}{l}\text { - A new group can get involved in easily. } \\
\text { - Group activity I can join without hesitation. } \\
\text { - When you need it from others I can easily ask for help. } \\
\text { - I can adapt easily to change. }\end{array}$ & 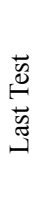 & $* * 26$ & $* * 3.89$ & $* .568$ & 53 & 3.04 & .004 \\
\hline Intellectual self-sufficiency & & $\mathbf{N}$ & $\bar{X}$ & $\mathbf{S}$ & SD & $\mathbf{t}$ & $\mathbf{p}$ \\
\hline $\begin{array}{l}\text { - Knowledge of literature I trust. } \\
\text { - Education policies in different disciplines I can evaluate on the basis of. } \\
\text { - About social problems solution I can improve it. } \\
\text { - The philosophy of education by taking advantage of training }\end{array}$ & $\begin{array}{l}\vec{y} \\
\stackrel{0}{\oplus} \\
\stackrel{0}{0}\end{array}$ & $* * 26$ & $* * 3.84$ & $* * .78$ & 53 & -.680 & .499 \\
\hline $\begin{array}{l}\text { I can evaluate the system. } \\
\text { - Current developments in the education system not that I can interpret. } \\
\text { - Sociological perspective on the society I live in I can evaluate. } \\
\text { - Current issues from a scientific perspective I can evaluate. }\end{array}$ & 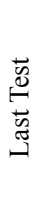 & $* * 26$ & $* * 3.92$ & $* * .533$ & 53 & 2.224 & .030 \\
\hline Scale-General & & $\mathbf{N}$ & $\bar{X}$ & $\mathbf{S}$ & SD & $\mathbf{t}$ & $\mathbf{p}$ \\
\hline & 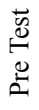 & $* * 26$ & $* * .63$ & $* * 3.72$ & 53 & -.956 & .344 \\
\hline & 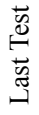 & $* * 26$ & $* * 3.97$ & $* * .48$ & 53 & 3.264 & .002 \\
\hline
\end{tabular}

Note. * Experimental group, **the control group.

There was no significant difference between the pre-test scores of the professional self-efficacy of the experimental and control groups $[\mathrm{t}(53)=-.413, \mathrm{p}>.05]$. The mean scores of the self-efficacy $(\bar{X}=3.91)$ of the prospective teachers and the self-efficacy mean score of the prospective teachers in the control group $(\bar{X}=3.98)$ were similar. Accordingly, there is no obvious difference between the experimental and control groups' professional self-efficacy beliefs before the procedure. On the other hand, there is a significant difference between the post-test scores of the professional self-efficacy $[\mathrm{t}(42.93)=2.694, \mathrm{p}<.05]$. These results show that after the micro-teaching practices, the experimental group found themselves more adequate in terms of professional self-efficacy belief than the control group.

There was no significant difference between the social self-efficacy pretest scores of the experimental and control groups $[\mathrm{t}(53)=.247, \mathrm{p}>.05]$. Social self-efficacy averages $(\bar{X}=$ $3.84)$ of prospective teachers in the experimental group and social self-efficacy average of prospective teachers in the control group $(\bar{X}=3.78)$ were similar. According to this, there is 
no obvious difference between the experimental and control groups' social self-efficacy beliefs before the procedure. However, there is a significant difference between the social self-efficacy post test scores of the experimental and control groups $[t(53)=3.034, p<.05]$. These results show that after the micro-teaching practices, the experimental group found themselves more adequate in terms of their social self-efficacy belief than the control group.

There was no significant difference between the intellectual self-efficacy pre-test scores of the experimental and control groups $[\mathrm{t}(53)=.680, \mathrm{p}>.05]$. It is seen that the intellectual self-efficacy mean scores of the prospective teachers in the experimental group $(\bar{X}=3.71)$ and the intellectual self-efficacy mean scores of the prospective teachers in the control group $(\bar{X}=3.84)$ were similar. According to this, it can be said that there is no obvious difference between the experimental self-efficacy beliefs of the experimental and control groups. However, a significant difference can be observed between the intellectual self-efficacy post test scores of the experimental and control groups $[\mathrm{t}(53)=2.224, \mathrm{p}<.05]$. These results show that after the micro-teaching practices, the experimental group considered themselves more adequate than the control group in terms of intellectual self-efficacy belief.

There was no significant difference between the self-efficacy pre-test scores of the experimental and control groups from the scale $[\mathrm{t}(53)=-.956, \mathrm{p}>.05]$. Total self-efficacy mean scores of the prospective teachers in the experimental group $(\bar{X}=3.72)$ and total self-efficacy mean of prospective teachers in the control group $(\bar{X}=3.89)$ were similar. According to this, it can be said that experimental and control groups have a high average value of general teaching self-efficacy belief before the procedure, but there are no significant differences between the groups. However, there is a significant difference among the post test scores obtained from the scale $[\mathrm{t}(53)=3.264, \mathrm{p}<.05]$. These results show that after the micro-teaching practices, the experimental group considered themselves more adequate in terms of teaching self-efficacy belief than the control group.

Table 5 shows the average $(\bar{X})$ and standard deviation $(\mathrm{S})$ values of prospective teacher self-efficacy total scores according to the experimental and control groups.

Table 5. Involved in the experimental and control groups of teachers' self-efficacy score of the candidate mean and standard deviation values

\begin{tabular}{|l|l|l|l|l|l|l|}
\hline \multirow{2}{*}{ Group } & \multicolumn{3}{|c|}{ Pre-test } & \multicolumn{3}{c|}{ Last-test } \\
\cline { 2 - 8 } & $\mathbf{N}$ & $\overline{\boldsymbol{X}}$ & $\mathbf{S}$ & $\mathbf{N}$ & $\overline{\boldsymbol{X}}$ & $\mathbf{S}$ \\
\hline Experiment & 29 & 3.72 & .63 & 29 & 4.35 & .37 \\
\hline Control & 26 & 3.89 & .64 & 26 & 3.97 & .48 \\
\hline
\end{tabular}

As seen in Table 5, the pre-test mean score of the prospective teachers who were taught using micro-teaching method was 3.72 before the experiment and this value was 4.35 after the experiment. The number of prospective teachers who were taught with traditional teaching 
methods and techniques was 3.89 before the experiment and this value was 3.97 after the experiment. Hence, it can be said that there is an increase in the teacher self-efficacy beliefs of prospective teachers who were taught with both micro-teaching and traditional teaching method.

Two-factor ANOVA results are given in Table 6 regarding whether there is a significant difference in the teacher self-efficacy beliefs of the prospective teachers exposed to two different experimental processes.

Table 6. Teacher candidates' pre-test and post test score on the two-way ANOVA results

\begin{tabular}{|l|l|l|l|l|l|}
\hline Source of variance & Sum of squares & SD & Average of squares & F & p \\
\hline Between subjects & 24.526 & 54 & .777 & & \\
\hline Group (experimental/control) & .320 & 1 & .320 & .701 & .406 \\
\hline Error & 24.206 & 53 & .457 & & \\
\hline The subjects inside & 12.725 & 55 & 5.625 & & \\
\hline Measurement (pre-post test) & .449 & 1 & 3.449 & 25.257 & .000 \\
\hline Group Measure & $\mathbf{2 . 0 3 9}$ & $\mathbf{1}$ & $\mathbf{2 . 0 3 9}$ & $\mathbf{1 4 . 9 3 0}$ & $\mathbf{. 0 0 0}$ \\
\hline Error & 7.237 & 53 & .137 & & \\
\hline Total & 37.251 & & & & \\
\hline
\end{tabular}

When Table 6 was examined, a significant difference was found between the pre-test and post-test teacher self-efficacy beliefs scores of prospective teachers $\left[F_{(1-53)}=25.257 ; p<.05\right]$. This finding can be interpreted that the self-efficacy scores of the prospective teachers differ from the overall scale regardless of the group experimental and control).

It was found that the pre-test and post-experiment measurement results of the prospective teachers' self-efficacy belief scores differed from each other significantly. It can be said that the common effects of repeated measurement factors in different process groups on teacher self-efficacy belief were significant $\left[\mathrm{F}_{(1-53)}=14,930, \mathrm{p}<.05\right]$. This result shows that performing micro-technique and traditional teaching methods have different effects on teacher self-efficacy beliefs of prospective teachers.

Micro-teaching technique which scores more points in teacher self-efficacy beliefs compared to before of the experiment, was found more effective than the teaching methods and techniques used to increase teacher self-efficacy beliefs. In order to prove this, the difference between the post-test and pre-test scores of the prospective teachers in both groups was calculated and progress points series were formed. This difference/progress point mean, which is an indicator of the progress of the experimental and control groups in the process, was compared with the unrelated samples t-test. The obtained t-test results are given in Table 7. 
Table 7. T-Test results of difference points by groups

\begin{tabular}{|l|l|l|l|l|l|l|}
\hline Difference & $\mathbf{N}$ & $\overline{\boldsymbol{X}}$ & $\mathbf{S}$ & $\mathbf{S D}$ & $\mathbf{t}$ & $\mathbf{p}$ \\
\hline Experiment & 29 & .62 & .45 & 53 & 3.864 & .000 \\
\hline Control & 26 & .08 & .58 & & & \\
\hline
\end{tabular}

When Table 7 is examined, it can be seen that the mean of progress points in the experimental group that applied micro-teaching technique $(\bar{X}=.62)$ is significantly different from the mean of progress points in the control group $(\bar{X}=.08)$ having used the traditional teaching methods and techniques $(\mathrm{t}(53)=3.864, \mathrm{p}<.05)$. In this case, it can be said that micro-teaching technique has a significant effect on teacher self-efficacy beliefs.

\section{Conclusion, Discussion and Suggestions}

According to the findings of this research, the pedagogical formation program of the micro-teaching technique was significantly influential in increasing the teacher self-efficacy beliefs. It was found that the total self-efficacy pretest scores of the micro-teaching group and the traditional teaching group were high. However, it was also found that this trend does not lead to significant differences between the groups. The reasons for the high level of self-efficacy for the teaching profession of the graduates of the faculties of science and literature who do not have any prior knowledge for educational sciences during the undergraduate education should be investigated separately. On the other hand, there was a significant difference between the post-test scores obtained from the overall scale $[\mathrm{t}(53)=$ $3.264, \mathrm{p}<.05]$. These results show that after the micro-teaching practices, the experimental group considered themselves more adequate in terms of teaching self-efficacy belief than the control group. According to the result of the study, it also provided important outcomes in terms of all sub-dimensions of academic self-efficacy scale (academic, professional, social and intellectual). In other words, their teaching self-confidence increased significantly. In the literature, there are no other studies investigating the self-efficacy scale in these four sub-dimensions. In general, we find that the findings of independent features describing self-efficacy feature are included. As for the main achievements in our research findings: Significant changes occurred in the self-confidence, motivation, effective communication and classroom management skills of prospective teachers who had the opportunity to get experience without entering real classroom environments. Furthermore, it is understood that they consider themselves generally sufficient in terms of traits such as interpreting the developments in the education system, introducing solutions to social problems, participating in group work and providing assistance, and providing effective communication with the parents.

There are many experimental studies on micro-teaching in all of the articles and theses at the undergraduate level and conducted in Turkey; and it is seen that qualitative studies are given less importance than experimental studies (Güven, Kahveci, Öztürk, \& Akın, 2016). As examples of some studies recently conducted in Turkey: Altunçekiç, Yaman, and Koray 
(2005); Atav, Kunduz, and Seçken (2014); Bakaç and Raşit (2017); Baştürk and Dönmez (2011); Bilen (2014); Canbazoğlu and Yamak (2014); Bilici and Güler (2016); Sendurur (2018); Karadağ and Akkaya (2013); Taflı and Atıcı (2018); Tok (2016) can be given. In the study about first reading-writing course micro-teaching practices conducted by Karadağ and Akkaya (2013), it is stated that micro-teaching practices significantly help prospective teachers gain self-confidence and gain professional knowledge and skills. In another study conducted by Bilen (2014) in order to determine the effect of micro-teaching technique on the teaching behaviors of prospective teachers, it was found out that prospective teachers liked micro teaching practices, learned about teaching skills with this practice, increased their self-confidence and teaching skills. In the study titled Teachers' Opinions on Micro-Teaching Practices in Biology Education, conducted by Atav, Kunduz, and Seçken (2014), it was concluded that micro-teaching is useful for the prospective teachers to correct their deficiencies in terms of teaching skills and to develop positive attitudes towards the profession. In another study conducted on prospective teachers Canbazoğlu and Yamak (2014) stated that the sharing of micro-teaching videos online and the application of micro-teaching in both a university and a real class environment contributed to the professional knowledge of teaching. As can be seen, research findings on prospective teachers in this field; focus on the idea that micro-teaching practices are useful in developing an understanding of the teaching profession, that they contribute to love of the profession, that they deem application mistakes more acceptable, that self-efficacy facilitates the development of psycho-motor skills, and that the importance of verbal expression matters.

It can be said that the teacher self-efficacy perceptions, which is another dimension of the research, are high in the prospective teachers. The result obtained is consistent with the results obtained from the studies conducted by Akyıldız (2017), Çocuk, Kanadlı, and Karakuş (2016), Yıldız (2018), Yokuş and Tanrıseven (2015), Yeşilyurt (2013) to determine the teachers' self-efficacy levels, participating in the PFSP. From these studies, Çocuk, Yokuş, and Tanriseven (2015) attributed high self-efficacy to the effectiveness of PFSP. Y1ldiz (2018) found that self-efficacy beliefs of prospective music teachers reflect a high level and that all sub-dimensions of the scale support this result. Sunjin (2010), while listing the variables that directly affect teacher self-efficacy, he highlighted the following points "student achievement, student motivation, learning and adoption of the developments in the field, success of implementation of the education program, making specific training decisions for students who require special education, teacher's professional commitment, teachers' classroom management strategies". Teachers' self-efficacy belief and perceptions of their courses have also been shown to contribute to their professional competence (Ashton, Webb, \& Doda, 1983; Milner, 2002; Zimmerman, 1995).

The results of these researches in question and similar research results show that micro teaching practices can be used as an effective technique in teacher education. In these researches, it is pointed out that micro teaching technique focusing on teaching and education is an effective technique in developing professional self-confidence. However, it is also stated that micro teaching practices applied in universities are not given enough importance and cannot be extended. Nevertheless, prospective teachers are expected to gain skills during the 
process of candidacy, in order to ensure the learning environment, and the regulation, control and change of student behavior. In upgrading the quality of education, solving problems encountered in the teaching process, teachers' personal judgment, self-efficacy beliefs and perceptions about their abilities and skills play an important role. School experience I and II applications and Special Teaching Methods courses which are included in the education programs of the Faculties of Education in Turkey are the courses that have an important role in developing the competence and skills of prospective teachers. It is believed that more widespread application of micro teaching and similar methods and techniques in these courses will make a significant contribution to the professional self-efficacy of the prospective teacher.

In the development of self-efficacy beliefs of pedagogical formation prospective teachers with various undergraduate degrees, modular modeling can be performed in eclectic structure with school experience applications. In the beginning phase of this teaching model, the teaching faculties can be given micro-teaching theory and applications that are provided with teaching tools and materials within the framework of teaching formation courses. The second phase of the model should be continued at the city centers where schools of education/faculties of education are located. For this purpose, micro-teaching application classes or classes can be created in which both school teachers and prospective teachers can benefit and share their knowledge and experiences. A comprehensive program arrangement can be considered for the effective implementation of this understanding.

\section{References}

Akbulut, E. (2006). Müzik öğretmeni adaylarının mesleklerine ilişkin öz-yeterlik inançları. Yüzüncü Yıl Üniversitesi Eğitim Fakültesi Dergisi, 2, 24-33.

Akkoyunlu, B., Orhan, F., \& Umay, A . (2005). Bilgisayar öğretmenleri için "bilgisayar öğretmenliği öz-yeterlik ölçeği” geliştirme çalışması. Hacettepe Üniversitesi Eğitim Fakültesi Dergisi, 29, 1-8.

Akyıldız, S. (2014). Lise öğretmenlerinin epistemolojik inançları ile öğretme-öğrenme anlayışları arasındaki ilişkinin incelenmesi (Unpublished doctoral dissertation, Firat University, Elazı ̆̆g, Turkey).

Allen, D. W. (1967). Micro-teaching: A description (Document Reproduction Service ED 019 224). Stanford University, Education Resources Information Center (ERIC).

Altunçekiç, A., Yaman, S., \& Koray, Ö. (2005). Öğretmen adaylarının özyeterlik inanç düzeyleri ve problem çözme becerileri üzerine bir araştırma (Kastamonu ili örneği). Kastamonu Ĕ̆itim Dergisi, 13(1), 93-102.

Arastaman, G. (2013). Eğitim ve fen edebiyat fakültesi öğrencilerinin öz-yeterlik inançları ve öğretmenlik mesleğine karşı tutumlarının incelenmesi. Ahi Evran Üniversitesi Kırşehir Eğitim Fakültesi Dergisi, 14(2), 205-217.

Ashton, P. T., Webb, R. B., \& Doda, N. (1983). A study of teachers' sense of efficacy. Final report executive summary. Gainesville, FL: University of Florida. 


\section{Macrothink}

Aşkar, P., \& Umay, A. (2001). İlköğretim matematik öğretmenliği öğrencilerinin bilgisayarla ilgili öz-yeterlik algısı. Hacettepe Üniversitesi Eğitim Fakültesi Dergisi, 21, 1-8.

Atav, E., Kunduz, N., \& Seçken, N. (2014). Biyoloji eğitiminde mikro-öğretim uygulamalarına dair öğretmen adaylarının görüşleri. Hacettepe Üniversitesi Ĕ̈itim Fakültesi Dergisi, 29(4).

Bakaç, E., \& Özen, R. (2017). Pedagojik formasyon öğrencilerinin öğretmenlik mesleğine yönelik öz-yeterlik inançları ile tutumları arasındaki ilişki. Kastamonu Ĕgitim Dergisi, 25(4).

Bandura, A. (1977). Self-efficacy: Toward a unifying theory of behavioral change. Psychological Review, 84(2), 191-215. https://doi.org/10.1037//0033-295X.84.2.191

Bandura, A. (1982). Self-efficiacy mechanism in human agency. American Psychologist, 37(2), 122-147. https://doi.org/10.1037//0003-066X.37.2.122

Bandura, A. (2006). Guide for constructing self-efficacy scales. Self-efficacy Beliefs of Adolescents, 5, 307-337.

Baştürk, S., \& Dönmez, G. (2011). Matematik öğretmen adaylarının pedagojik alan bilgilerinin ölçme ve değerlendirme bilgisi bileşeni. Ahi Evran University. Journal of Kırşehir Education Faculty, 12(3), 17-37.

Bayraktar, E. (1982). Mikro-öğretim yöntemi ve uygulaması. Yayımlanmamış Asistanlık Tezi, Kız Teknik Öğretmen Okulu, Ankara.

Benton-Kupper, J. (2001). The microteaching experience: Student perspectives. Education, 121(4), 830-836.

Berg, M. H., \& Smith, J. P. (1996). Using videotapes to 1mprove teaching. Music Educators Journal, 4(82), 31-37. https://doi.org/10.2307/3398914

Bıkmaz, F. H. (2004). Öz-yeterlik inançları. In Y. Kuzgun, \& D. Deryakulu (Eds.), Ĕgitimde bireysel farklılıklar (pp. 289-308). Ankara: Nobel Yayın Dağıtım.

Bilen, K. (2014). Mikro-öğretim tekniği ile öğretmen adaylarının öğretim davranışlarına ilişkin algılarının belirlenmesi. Erzincan Üniversitesi Ĕ̆itim Fakültesi Dergisi, 16(1). https://doi.org/10.17556/jef.36672

Bilen, M. (1996). Plandan uygulamaya öğretim. Ankara: Anı Yayıncılık.

Bilici, S., \& Güler, Ç. (2016). Ortaöğretim öğretmenlerinin tpab düzeylerinin öğretim teknolojilerini kullanma durumlarına göre incelenmesi. Ilköğretim Online, 15(3), 898-921. https://doi.org/10.17051/io.2016.05210

Bisset, R. T. (1999). The knowledge bases of the expert teacher. British Educational Research Journal, 25(1), 39-55. https://doi.org/10.1080/0141192990250104

Blankenburg, R. M., \& Thompson, A. G. (1971). Microteaching. Momentum, 2(1), 35-37. https://doi.org/10.1080/00131727109340447 
Bourdoncle, R. (1989). La professionnalisation des enseignants: Analyses sociologiques anglaises et Américaines. Revue Française De Pédagogie, 94, 73-92. https://doi.org/ 10.3406/rfp.1991.1368

Bümen, N. T., \& Ercan-Özaydın, E. (2013). Adaylıktan göreve öğretmen özyeterliği ve öğretmenlik mesleğine yönelik tutumlardaki değişimler. Ĕgitim ve Bilim, 38(169), 109-125.

Büyüköztürk, Ş. (2002). Veri analizi el kitabı: Ístatistik, araştırma deseni, SPSS uygulamaları ve yorum. Ankara: Pegem Akademi.

Çakır, Ö., \& Aksan, Y. (1992). Yabancı dil öğretmeni yetiştirmede mikro-öğretimin rolü: Bir model. Hacettepe Üniversitesi Ĕ̈itim Fakültesi Dergisi, 7, 313-320.

Can, A. (2014). SPSS ile bilimsel araştırma sürecinde nicel veri analizi (3 Baskı). Ankara: Pegem Akademi.

Canbazoğlu Bilici, S., \& Yamak, H. (2014). Teknolojik pedagojik alan bilgisi temelli bir araştırmada öğretmen adaylarının mikro-öğretim hakkındaki görüşleri. Mehmet Akif Ersoy Üniversitesi Eğitim Fakültesi Dergisi, 32(1).

Çapa, Y., Çakıroğlu, J., \& Sarıkaya, H. (2005). The development and validation of a Turkish version of teachers' sense of efficacy scale. Ë̆itim ve Bilim, 30(137), 74-81.

Cerit, Y. (2010). Teacher efficacy scale: The study of validity and reliability and preservice classroom teachers' self efficacy beliefs. Journal of Theory and Practice in Education, 6(1), 68-85.

Çocuk, H. E., Yokuş, G., \& Tanrıseven, I. (2015). Pedagojik formasyon öğrencilerinin öğretmenliğe ilişkin öz-yeterlik ve metaforik algıları: Mersin üniversitesi örneği. Mustafa Kemal Üniversitesi Sosyal Bilimler Enstitüsü Dergisi, 12(32), 373-387.

Çolak, İ., Yorulmaz, Y., \& Altınkurt, Y. (2017). Öğretmen öz-yeterlik inancı ölçeği geçerlik ve güvenirlik çalışması. Muğla Sıtkı Koçman Üniversitesi Eğitim Fakültesi Dergisi, 4(1), 20-32. https://doi.org/10.21666/muefd.319209

Cooper, J. M., \& Allen, D. W. (1970). Micro-teaching: History and present status (Document Reproduction Service ED 036-471). Education Resources Information Center (ERIC), Stanford University.

Cotrell, C. J., \& Doty, C. R. (1971). Assessment of micro-teaching and video recording in vocational and technical teacher education: Phase IV-Classroom Application of Micro-Teaching and Video Recording (Final Report, ED 057-192).

Demirel, Ö. (2000). Plandan uygulamaya ögretme sanatı. Ankara: PegemA Yayıncılık.

Diken, İ. H. (2004). Öğretmen yeterlik ölçeği: Türkçe uyarlaması, geçerlik ve güvenirlik çalışması. Eurasian Journal of Educational Research, 16, 102-112.

Duran, H. (2001). Bir meslek olarak öğretmenlik. Eskişehir: Anadolu Üniversitesi.

Ekici, G. (2009). Biyoloji öz-yeterlik ölçeğinin Türkçeye uyarlanması. Kastamonu Eğitim 
Dergisi, 17(1), 111-124.

Emmer, E. T., \& Hickman, J. (1991). Teacher efficacy in classroom management and discipline. Educational and Psychological Measurement, 51(3), 755-765. https://doi.org/ $10.1177 / 0013164491513027$

Fernández, M. L., \& Robinson, M. (2006). Prospective teachers' perspectives on micro-teaching lesson study. Education, 127(2), 203-215.

Gündüz, H. B. (2012). In M. D. Karslı (Ed.), Eğitim bilimine girişs (4 Baskı, pp. 217-240). Ankara: PegemA Yayınc1lık.

Güven, S., Kahveci, Ö., Öztürk, Y., \& Akın, Ö. (2016). Türkiye'de mikro-öğretim uygulamalarıyla ilgili yapılan çalışmaların içerik analizi. The Journal of International Lingual Social and Educational Sciences, 2(1), 19-34.

Higgins, A., \& Nicholl, H. (2003). The experiences of lecturers and students in the use of micro-teaching as a teaching strategy. Nurse Education in Practice, 3, 220-227. https://doi.org/10.1016/S1471-5953(02)00106-3

Jacques, D. (2000). Learning in groups: A handbook for improving group work (3rd ed.). London: Kogan Page.

Kahyaoğlu, M., \& Yangın, S. (2007). İlköğretim öğretmen adaylarının mesleki öz-yeterliklerine ilişkin görüşleri. Kastamonu Eğitim Dergisi, 15(1).

Kalaycı, Ş. (2006). SPSS uygulamalı çok değişkenli istatistik teknikleri. Ankara: Asil Yayın Dağıtım.

Karadağ, R., \& Akkaya, A. (2013). İlk okuma yazma öğretimi dersinde mikro öğretim uygulamalarına ilişkin öğretmen adaylarının görüssleri. Ahi Evran üniversitesi Kırşehir Eğitim Fakültesi Dergisi, 14(2), 39-59. https://doi.org/10.17240/aibuefd.2014.14.1-5000091505

Karasar, N. (2011). Bilimsel araştırma yöntemi. Ankara: Nobel Yayınevi.

Kavcar, C. (2002). Cumhuriyet döneminde dal öğretmeni yetiştirme. Ankara Üniversitesi Ĕ̈itim Bilimleri Fakültesi Dergisi, 35(1), 1-14. https://doi.org/10.1501/Egifak_0000000058

Kazu, H. (1997). Öğretmen yetiştirmede mikro-ögretim yönetiminin etkililiği: F.Ü. Teknik Eğitim Fakültesi örneği. IV Ulusal Eğitim Bilimleri Kongresi, 10-12 Eylül, Anadolu Üniversitesi, Eskişehir.

Kepçeoğlu, M. (1988). Psikolojik danışma ve rehberlik. Ankara: Kadığlu Matbaası.

Kpanja, E. (2001). A study of the effects of video tape recording in microteaching training. British Journal of Educational Technology, 32, 483-486. https://doi.org/10.1111/1467-8535. 00215

Mangal, S. K., \& Mangal, U. (2008). Teaching of social studies. New Delhi: PHI Learning.

MEB. (2008). Öğretmen yeterlilikleri. Ankara: Öğretmen Yetiştirme ve Eğitimi Genel 
Müdürlüğü. MEB Yayınları.

Milner, R., \& Hoy, A. W. (2002). Respect, social support and teacher efficacy: A case study. American Educational Research Association, 26, 1-10.

Mohan, R. (2011). Teacher education. New Delhi: PHI Learning.

Morgil, İ., Seçken, N., \& Yücel, A. S. (2004). Kimya öğretmen adaylarının öz-yeterlik inançlarının bazı degiskenler açısından incelenmesi. Balıkesir Üniversitesi Fen Bilimleri Enstitüsü Dergisi, 6(1), 62-72.

Nortman, M. L. (1989). The effects of the student teaching experience on educational attitudes. Dissertation Abstract International, 50(5), November, 119-A.

Oğuz, A., \& Topkaya, N. (2008). Ortaöğretim alan öğretmenliği öğrencilerinin öğretmen öz-yeterlik inançları ile öğretmenliğe ilişkin tutumları. Akademik Bakış, 14(1), 23-36.

Orlich, D. C., et al. (1990). Teaching strategies (3rd ed.). Canada: Heat and Company.

Özdemir, S. (2008), E-Learnings effect on knowledge. Can you download tacit knowledge. British Journal of Educational Technology, 39(3). https://doi.org/10.1111/j.1467-8535.2007. 00764.x

Palanc1, M. (2004). Üniversite ögrencilerinin sosyal kaygl problemlerini açıklama ve gidermeye yönelik gerçeklik terapisi oryantasyonlu bir yardım programının geliştirilmesi. Yayımlanmamış doktora tezi. Trabzon: Karadeniz Teknik Üniversitesi Sosyal Bilimler Enstitüsü.

Redmond, B. F. (2015). Self-efficacy and Social Cognitive Theory. Retrieved from https://wikispaces.psu.edu

Sendurur, U. (2018). Müzik dinleme etkinliklerinin ilköğretim öğrencilerinin akademik başarısına etkisi. Illkögretim Online, 17(1).

Senemoğlu, N. (2009). Gelişim öğrenme ve ögretim: Kuramdan uygulamaya (Geliştirilmiş 15. Bask1). Ankara: PegemA.

Şişman, M. (2000). Öğretmenlik mesleğine giriş. Ankara: PegemA Yayıncılık.

Sunjin, O. (2010). The sources that influence student teachers'sense of efficacy (Unpublished $\mathrm{PhD}$ Dissertation, Iowa State University Paper 11781).

Tezcan, M. (1997). Ĕğitim sosyolojisi. Ankara: Olgaç Matbaası.

Tok, Ş. (2016). Mikro-öğretim yönteminin öğretmen adaylarının öz-yeterlik inançlarına ve mesleğe yönelik tutumlarına etkisi. Milli Ĕgitim Dergisi (Sayı 212).

Tschannen-Moran, M., \& Hoy, A. W. (2001). Teacher efficacy: Capturing an elusive construct. Teaching and Teacher Education, 17(7), 783-805. https://doi.org/10.1016/S0742-051X(01) 00036-1

Üstün, A., \& Tekin, S. (2009). Amasya eğitim fakültesi öğretmen adaylarının öz-yeterlik 


\section{Macrothink}

inançlarının çeşitli değişkenler açısından karşılaştırılması. Bolu Abant İzet Baysal Üniversitesi Eğitim Fakültesi Dergisi, 9(1), 35-47.

Uşun, S., \& Zorlubaş, A. (2007). Mikro-öğretim yöntemi ile öğretmen yetiştirme. 1. Uluslararası bilgisayar ve ögretim teknolojileri eğitimi sempozyumu bildiri kitapçı̆̆ı (pp. 1940-1952). Çanakkale on Sekiz Mart Üniversitesi yayınları.

Woolfolk, A. E. (1998). Educational psychology. Boston: Allyn \& Bacon Pub.

Yıldırım, F., \& İlhan, İ. Ö. (2010). Genel öz-yeterlilik ölçeği Türkçe formunun geçerlik ve güvenirlik çalışması. Türk Psikiyatri Dergisi, 21(4), 301-308.

Yıldız, Y. (2018). Müzik öğretmeni adaylarının öz yeterlik inançlarının ve mesleğe yönelik tutumlarının incelenmesi. The Journal of Academic Social Science Studies, 71, 113-135. https://doi.org/10.9761/JASSS7805

Zimmerman, B. J. (1995). Self-efficacy and educational development (A Bandura, Der.). Self-efficacy in Changing Societies. New York: Cambridge University Press.

\section{Copyright Disclaimer}

Copyright for this article is retained by the author(s), with first publication rights granted to the journal.

This is an open-access article distributed under the terms and conditions of the Creative Commons Attribution license (http://creativecommons.org/licenses/by/3.0/). 